\title{
SHANK1 and autism spectrum disorders
}

\author{
GONG XiaoHong * \& WANG HongYan* \\ MOE Key Laboratory of Contemporary Anthropology and State Key Laboratory of Genetic Engineering, School of Life Sciences, \\ Fudan University, Shanghai 200433, China
}

\begin{abstract}
Autism spectrum disorders (ASD) are highly heterogeneous pediatric developmental disorders with estimated heritability more than $70 \%$. Although the genetic factors in ASD are mainly unknown, a large number of gene mutations have been found, especially in genes involved in neurogenesis. The Neurexin-Neuroligin-Shank (NRXN-NLGN-SHANK) pathway plays a key role in the formation, maturation and maintenance of synapses, consistent with the hypothesis of neurodevelopmental abnormality in ASD. Presynaptic NRXNs interact with postsynaptic NLGNs in excitatory glutamatergic synapses. SHANK proteins function as core components of the postsynaptic density (PSD) by interacting with multiple proteins. Recently, deletions and point mutations of the SHANK1 gene have been detected in ASD individuals, indicating the involvement of SHANK1 in ASD. This review focuses on the function of SHANK1 protein, Shank1 mouse models, and the molecular genetics of the SHANK1 gene in human ASD.
\end{abstract}

autism spectrum disorders, SHANK1, synapse, genetics, mouse model

Citation: $\quad$ Gong XH, Wang HY. Shank1 and autism spectrum disorders. Sci China Life Sci, 2015, 58: 985-990, doi: 10.1007/s11427-015-4892-6

Autism spectrum disorder (ASD) is a complex neurodevelopmental disease characterized by impaired social interaction and language development and repetitive and stereotyped behaviors and interests. ASD is more frequent in males than females, with an approximate ratio of $4: 1$ [1]. Twin and family studies indicate that genetic factors play an important role in the etiology of autism with the heritability estimate more than $90 \%$ [2,3]. Though the causes of ASD are largely unknown, neurexin-neuroligin-shank (NRXNNLGN-SHANK) pathway genes mutations have been implicated in ASD [4-20]. NLGN proteins, expressed highly in the brain, are postsynaptic adhesion molecules interacting with presynaptic NRXNs [9]. SHANK proteins function as core components of the postsynaptic density (PSD) by interacting with multiple proteins [21]. The impact of this pathway on synaptic function provides an important perspective for understanding the pathogenesis of ASD. The SHANK family has three members: SHANK1,

*Corresponding author (email: gongxh@fudan.edu.cn; wanghy@fudan.edu.cn)
SHANK2 and SHANK3. All SHANK family members are expressed in the brain and are present at PSD of excitatory synapses. SHANK3 was the first and one of the best characterized genes implicated in ASD in SHANK family [19,20]. Recently, deletions and point mutations of the SHANK1 gene have been detected in ASD individuals, indicating the involvement of SHANK1 in ASD [22]. This review focuses on the function of SHANK1 protein, Shank1 mouse models, and the molecular genetics of the SHANKI gene in human ASD.

\section{The structure and function of SHANK1 protein}

All three SHANK proteins have similar sets of domains: N-terminal multiple ankyrin repeats, a Src homology 3 (SH3) domain, a PSD-95/Discs large/ZO-1 (PDZ) domain, a long proline-rich region containing homer- and cortactin-binding sites, and a sterile alpha motif (SAM) domain. 
Through these multiple domains, SHANK family proteins interact with more than 30 synaptic proteins, consistent with the function of scaffolding proteins [23].

The major reported directly interacting proteins with SHANKs are GKAP (guanylate kinase-associated protein), GRIP (glutamate receptor-interacting protein), Homer and Cortactin. GKAP binds to the SHANK PDZ domain by $\mathrm{C}$ terminus sequence QTRL and interacts with NMDA ( $N$-methyld-aspartate) receptor by PSD-95 protein [24,25]. GRIP protein interacts with SHANK by SH3 domain and also with membrane receptor AMPAR (AMPA-type glutamate receptor) [26,27]. There is a proline-serine-rich segment of more than 1,000 residues between PDZ domain and SAM domain, which mediates multiple sets of protein interactions by binding with SH3, EVH1 (enabled/ vasodilator-stimulated phosphoprotein homology 1) and WW domains. Homer protein family includes one EVH1 domain, interacting with SHANKs by PPXXF sequence $[28,29]$. Homer mediates release of intracellular calcium in response to receptor stimulation by binding with mGluRs (metabotropic glutamate receptors) and IP3 (inositol 1,4,5-trisphosphate) receptors. Cortactin is an F-actinbinding protein, recognizing KPPVPPKP sequence of proline-rich region of SHANKs by its $\mathrm{SH} 3$ domain. Cortactin is rich in contact sites of cell-matrix, lamellipodia of cultured cells and growth cones of neurons, mediating the organization of the actin cytoskeleton in the cell cortex and in dendritic spines [30,31]. Thus, SHANK has the potential to interact indirectly with three major classes of postsynaptic glutamate receptor via their interacting proteins: NMDA receptors via the PSD-95/GKAP complex, mGluRs via Homer, and AMPA receptors via GRIP. The C-terminal SAM domain is a region critical for the postsynaptic localization of SHANK2 and SHANK3 while SHANK1 utilizes its PDZ domain for its synaptic localization [32-34].

In rats, SHANK2 and SHANK3 are expressed widely in many tissues such as the brain, kidney, heart, liver and spleen while SHANK1 mRNA and protein are expressed almost exclusively in the brain $[35,36]$. In cultured developing neurons, SHANK is highly expressed in growth cones and accumulates at synaptic junctions [25,31]. Overexpression of SHANK1 alters spine morphology, leading to the enlargement of spine heads [34]. On the other hand, Shankl knockout mice have smaller spines than wild type, suggesting a role for SHANK1 in affecting the size of spines [37]. Depolarization elicits a significant increase in levels of SHANK1 in the contiguous network immediately below PSD and only a modest increase in SHANK2 [38]. Moreover, while the increase in SHANK1 is reversed in $30 \mathrm{~min}$, the increase in SHANK2 for the most part is maintained. These data indicate that SHANK1 is a dynamic element within the spine, involved in activity-induced, transient structural changes, while SHANK2 appears to be a more stable element of the postsynaptic complex [38].

Synaptic activity and excitatory stimuli elicit structural changes in spine morphology, a process called synaptic plasticity. These structural and molecular changes are believed to represent the basis for learning and memory. SHANK family members may play different roles in synaptogenesis and synapse maturation. Their levels at the PSD are tightly regulated via $\mathrm{Zn}^{2+}$ ions in an isoform-specific way [39]. SHANK2 and SHANK3 are sensitive to $\mathrm{Zn}^{2+}$ ions via their SAM domains, whereas SHANK1 is $\mathrm{Zn}^{2+}$ insensitive. Immature synapses exhibit a striking sensitivity to extracellular levels of $\mathrm{Zn}^{2+}$ ions that is not shared by mature synapses. This sensitivity is intimately linked to the differential expression and selective binding of $\mathrm{Zn}^{2+}$ ions to SHANK2 and SHANK3 but not SHANK1. SHANK family members are recruited consecutively to postsynaptic sites at different stages of development in primary hippocampal cultures. SHANK2 was the first to appear at PSDs, presented in all synapses while SHANK1 was detected in one third of all synapses at DIV (days in vitro) 7. During late development of synaptic contacts (DIV 21), 95\% of all synapses were labeled with all three SHANK family members [38]. Shank1 knockdown together with zinc depletion also reduced the number of "mushroom/stubby" synapses and leads to a shift towards smaller spine size [39].

Tissue-specific methylation is one of the mechanisms for regulation of gene expression. DNA methylation status of human SHANK genes was analyzed in lymphocytes, brain cortex, cerebellum and heart. Seven $\mathrm{CpG}$ islands of SHANK1 and SHANK2 genes and five of SHANK3 were identified and analyzed for DNA methylation [40]. The majority of the CpG islands in SHANK1 and SHANK2 show extensive variability in methylation without apparent tissue-specificity. SHANK3, on the other hand, undergoes tissue-specific methylation at most of its $\mathrm{CpG}$ islands and highly methylated in tissues where its expression is low or absent, suggesting that SHANK3 expression might be regulated by epigenetic mechanisms such as DNA methylation. Promoter-associated $\mathrm{CpG}$ islands of all SHANK members were always completely unmethylated.

\section{Mouse models of Shank1}

Shank1 mutant mice with a deletion of exons 14 and 15 were produced and characterized by Hung et al. [37] in 2008. These two exons encode almost the entire PDZ domain, a highly conserved region of Shankl. Since Shankl mutant mice in the B6 background had high mortality and Shankl mice in the 129Jae background strain had very low locomotion, two lines were crossed to obtain a mixed C57BL/6/129SvJae (B6/Jae) background. The molecular and behavioral phenotypes of Shankl mutant mice were studied. Shankl $1^{-1-}$ mutant mice showed altered protein composition of the PSD. There was a significant reduction of GKAP $(\sim 30 \%)$ and Homer1b/c ( 20\%), two scaffold proteins that bind directly with SHANK, while no signifi- 
cant difference in the levels of NMDA, AMPA, PSD-95, GRIP, $\beta$-PIX (PAK-interacting exchange factor- $\beta$ ) and cortactin. Consistent with the biochemical results, the density of GKAP puncta was significantly decreased in Shank1 ${ }^{-1-}$ mutant mouse brain. The immunostaining pattern of Homer was more diffuse though there was no significant change in density of Homer puncta in Shank1 $1^{-1-}$ knockout mouse brain. These data support the idea that SHANK1 is important for synaptic accumulation of GKAP and Homer. No gross abnormalities in the size or histological structure of the brain (including cortex, hippocampus, and cerebellum) were detected. In CA1 pyramidal neurons of hippocampus, significantly smaller spine size, reduced PSD thickness and a selective loss of the largest PSDs were observed in Shank1 ${ }^{-1-}$ knockout mice compared with wild type mice, suggesting that SHANK1 may be critical for the development and/or maintenance of the largest subset of PSDs and synapses in particular. Shank1 $1^{-1-}$ mutant mice showed decreased basal synaptic transmission as a result of a reduction in the number of functional synapses. The ratio of AMPAR and NMDAR EPSCs (excitatory postsynaptic currents) (AMPA/NMDA ratio) was not significantly different between wild type mice and Shank $1^{-1-}$ mutant mice, suggesting that the Shankl deficiency does not affect the proportion of synaptic AMPA and NMDA receptors.

The behavior of adult Shank $1^{-1-}$ mutant mice was investigated in a variety of assays [37]. Shank $1^{-1-}$ mutant mice were significantly less active in a novel open-field environment than the wild-type littermate control mice, as measured by horizontal activity, total distance traveled and movement time. Shank $1^{-1-}$ mutant mice showed increased anxiety-like behavior in open-field testing and the light/dark transition test. Shank1 $1^{-1-}$ homozygous mice were poor breeders, did not nurture their pups, and their litters generally died before weaning. Shank $1^{-1-}$ mutant mice have enhanced spatial learning but impaired long-term retention of this memory in eight-arm radial maze task in which animals must learn and remember the position of baited arms between trials while rapidly establishing memory of previously visited arms within a trial. In such a task, the Shank1 ${ }^{-1-}$ mutant mice showed a steeper learning curve and reached a better performance level with fewer reference memory errors and fewer working memory errors than the wildtype control mice. Together, these data indicate that Shankl deficient mice learn faster and more effectively during repetitive training in the eight-arm radial maze.

Autism has three core diagnostic symptoms including social communication deficits, language development delay, and stereotyped or repetitive behaviors and interests. Silverman et al. [41] developed multiple mouse behavioral assays to investigate autism-relevant phenotypes in Shankl mutant mice. Both females and males of all three genotypes $\left(\right.$ Shank $1^{-1-}$, Shank1 ${ }^{+/}$, and Shankl ${ }^{+/+}$) were tested in the study, while only Shank1 $1^{-1-}$ mutant males were studied in the first report of Shank $1^{-1-}$ knockout mice. Social behaviors were examined through three aspects: reciprocal social interactions in juvenile mice, adult sociability using automated three-chambered task in adult mice, and social interest in the olfactory habituation/dishabituation task. No genotype differences were observed for six parameters, i.e., nose-tonose sniff, anogenital sniff, body sniff, push-crawl, pushpast, and follow events, when characterizing active social interactions in juvenile Shankl mice. All of Shankl genotypes $(-/-,+/-$, and $+/+)$ failed to demonstrate significant sociability, which could not be attributed to their background strain since the hybrid B6/Jae mice showed normal sociability. Three potential explanations for the lack of sociability in the Shankl line were proposed by the authors. First, altered behavior of the Shank $1^{+/-}$mutant mother mice could affect performance on behavioral tasks via epigenetic modulation. Second, home cage interactions among littermate pups may affect later social performance. Third, genetic drift across generations could have introduced variations in the mixture of genes from the two original background strains across individual subject mice. Stereotyped and repetitive behaviors were measured by self-grooming in Shankl mutant mice. Though all Shankl genotypes mice exhibited high levels of self-grooming, no significant differences in self-grooming scores were detected across genotypes.

Anxiety-like behavior was assessed using the light/dark test and the elevated plus-maze task [41]. Shank $1^{-1-}$ mutant mice displayed significantly fewer transitions between the light and dark compartment as compared with Shankl ${ }^{+/+}$ and Shank $1^{+/-}$heterozygotes, consistent with previous findings. However, other parameters of the light/dark task and the elevated plus-maze task did not show difference across genotypes. The authors concluded that these results indicate a mild anxiety-like behavior attributable to the Shankl mutation.

The major phenotypes of Shank1 mutant mice were motor impairments evaluated using three tasks, open field, rotarod, and wire hang [41]. Shankl null mice displayed less total distance and spent less time in the center of the arena as compared to Shank1 ${ }^{+/+}$littermates in a novel open field. Shank $1^{-1-}$ null mutant mice fell from the accelerating rotarod faster and from the inverted wire mouse cage lid faster than Shank1 ${ }^{+/+}$and Shank1 ${ }^{+/-}$heterozygous littermate mice. Overall, Shank1 $1^{-1-}$ mutant mice showed reduced exploratory locomotion and reduced motor coordination, balance and neuromuscular strength.

Social communication of Shankl mutant mice was further evaluated using assays for ultrasonic vocalizations (USV) and scent marking in an open field, which are believed to be two major modes of mouse communication [42]. Deficits in several elements of social communication and early developmental milestones were detected in Shankl null mutant mice. Mouse pups emit USV when isolated 
from their mother and littermates to elicit maternal search and retrieval behavior [43-46]. In adult mice, high USV levels are detected in males when courting and copulating with females. Several genetic mouse models of autism were reported to display reduced levels of pup USV, unusual calling patterns, or reduced levels of male USV production in response to females or female urine [47-51]. As pups, Shank $1^{-1-}$ mutant mice emitted fewer USV and spent less time calling than Shank1 $1^{+/}$littermate control mice when isolated from mother and littermates [42]. Calls emitted by Shank $1^{-1-}$ mutant mouse pups were shorter, higher in peak frequency, but less frequency modulated than the ones emitted by Shank1 $1^{+/+}$control pups. These altered parameters of calls emitted by Shank $k^{-1-}$ mutant pups may decrease their signal value and elicit less maternal care-giving responses. As adults, Shankl ${ }^{+/+}$wildtype males changed their calling pattern dependent on their previous exposure to a female, but Shank $1^{-1-}$ mutant males were unaffected by prior female experience though both Shankl ${ }^{+/+}$and Shank1 ${ }^{-1-}$ male mice emitted a similar amount of USV when exposed to female urine. The lack of experience-induced changes in USV production may represent an inability to modulate social behaviors in response to experiences with social cues. In addition to USV, adult male mice display scent marking behavior, depositing urinary pheromone traces in close proximity to the location of female urine. Shank $1^{-1-}$ mutant mice deposited fewer urine traces in proximity to the female urine spot than Shank1 ${ }^{+/+}$littermate control mice. Reduced levels of locomotor behavior were observed in Shank ${ }^{-1-}$ mutant mice, replicating the previous studies. The surface righting reflex was delayed in Shank1 $1^{-1-}$ mutant as compared to Shankl ${ }^{+/+}$mice. Appearance of some physical developmental milestones, i.e. pinnae detachment and incisor eruption were delayed in Shank1 $1^{-1-}$ mutant pups [42].

\section{SHANK1 mutations are associated with ASD}

As compared with numerous reports of SHANK2 and SHANK3 mutations in ASD, there is so far only one report about the involvement of SHANK1 in ASD [22]. Copynumber variations (CNVs) screening was performed in a cohort of 1,158 unrelated Canadian individuals (898 males and 260 females) and 456 unrelated European individuals (362 males and 94 females) and sequence-level mutations of SHANK1 were tested in 509 unrelated ASD (384 males and 125 females) and 340 intellectual disability (ID, 191 males and 149 females) individuals by Sato et al. [22]. They initially identified a hemizygous microdeletion of $63.8 \mathrm{~kb}$ which eliminated exons 1-20 of SHANK1 and the neighboring CLEC11A gene in a four-generation family. Four male carriers were diagnosed with Asperger disorder or broader autism phenotype (BAP) whereas two female carriers exhibited anxiety and shyness but would not be consid- ered to have ASD or BAP. Another unrelated male case with the diagnosis of high-function autism was identified to have a de novo $63.4 \mathrm{~kb}$ hemizygous deletion which eliminated the last three exons of SHANK1 and the entire centromeric synaptotagmin-3 (SYT3) gene. No equivalent deletion was observed in 15,122 control individuals. The frequency of deletions at the SHANK1 locus is significantly higher in ASD cases than in controls. Remarkably, by whole-exome sequencing in two male individuals carrying the deletion of SHANK1 in the multigenerational family, a nonsense mutation (Tyr313*) in the PCDHGA11 gene, a member of the protocadherin gamma gene cluster thought to have an important role in establishing connections in the brain, was identified. The mutation was found to segregate precisely with the SHANK1 deletion. It is possible that the Tyr313* mutation in PCDHGA11 works in concert with the $S H A N K 1$ deletion to modify (positively or negatively) the extent of the phenotype or that they are just randomly cosegregating.

The segregation of ASD in only male SHANK1-deletion carriers, but not female carriers, indicates gender-influenced autosomal penetrance differences at the SHANK1 locus in ASD. SHANK1 deletions are associated with ASD with higher functioning in males. The female carriers do not show evidence of ASD or BAP but have suffered from anxiety, which is considered to be a common comorbid condition but not a related phenotype to ASD. These results may help to explain the male gender bias in autism. Females need to carry more genetic liability than males in order to develop ASD. Consistent with these findings in humans, Shankl null mice exhibit increased anxiety-related behavior and deficits in several elements of social communication and developmental milestones.

By sequencing of all exons and splice sites of the SHANK1 gene in 509 unrelated ASD and 340 ID individuals, 26 rare missense variants were identified in 23 ASD and 7 ID cases, which were not found in dbSNP (single nucleotide polymorphism) build 130 or in 285 control individuals [22]. Only two missense variants were predicted to be deleterious since they alter highly conserved residues within the PDZ domain and ANK (ankyrin) domain. Although they occurred in males with ASD, both variants were inherited with fathers with no symptoms of ASD.

Given that important roles of SHANK family in synaptic function and the detection of SHANK2 and SHANK3 mutations in ID and schizophrenia, it is reasonable to expect that SHANK1 mutations may contribute to other psychiatric disorders. Lennertz et al. [52] genotyped 5 common SNPs in SHANK1, SHANK2 and SHANK3 and found one SNP rs3810280 in promoter region of SHANK1 was associated with working memory in schizophrenia cases. This association was replicated in another cohort of 77 subjects with high risk of psychosis. Although the sample size was small, the association of SNPs of SHANK1 with schizophrenia indicates the involvement of SHANK1 in the pathogenesis 
of neurodevelopmental disorders.

\section{Perspectives}

Although all SHANK family members have similar structure, the interaction proteins for each SHANK and related functions could be different. For example, SHANK2 and SHANK3 utilize their SAM domain for oligomerization and synaptic localization, while the PDZ domain of SHANK1 is critical for its postsynaptic localization. The different temporal and spatial distribution of SHANK1 indicates its non-redundant function with other two SHANK members. The protein partners of SHANK1 and their specific functions at excitatory synapses need to be illuminated.

The male carriers of SHANK1 deletions were diagnosed with high-function autism. However, Shank $1^{-1-}$ mutant mice did not show robust social deficits. Mice lacking Shankl display smaller spine size, reduced PSD thickness and weaker basal synaptic transmission. On behavioral level, Shank $1^{-1-}$ mutant mice showed increased anxiety, enhanced spatial learning, motor impairments, and altered social communication (reduced levels of ultrasonic vocalizations and scent marking behavior). One interpretation could be that the absence of Shankl in mice may affect cognitive abilities including motor and spatial learning, instead of direct effect on sociability. Double knockout mice of Shanks, i.e. Shank1 and Shank2 double knockout mice, will be interesting model to investigate the expression pattern of synaptic proteins and behavioral phenotypes.

This work was supported by grants from National Basic Research Program of China (2010CB529601), Natural Science Foundation of Shanghai Municipality (13ZR1402100), and the National Natural Science Foundation of China (30900404).

1 Fombonne E. Epidemiological trends in rates of autism. Mol Psychiatry, 2002, 7(Suppl 2): S4-S6

2 Bailey A, Le Couteur A, Gottesman I, Bolton P, Simonoff E, Yuzda E, Rutter M. Autism as a strongly genetic disorder: evidence from a British twin study. Psychol Med, 1995, 25: 63-77

3 Szatmari P, Jones MB, Zwaigenbaum L, MacLean JE. Genetics of autism: overview and new directions. J Autism Dev Disord, 1998, 28: 351-368

4 Craig AM, Kang Y. Neurexin-neuroligin signaling in synapse development. Curr Opin Neurobiol, 2007, 17: 43-52

5 Bourgeron T. A synaptic trek to autism. Curr Opin Neurobiol, 2009, 19: 231-234

6 Buxbaum JD. Multiple rare variants in the etiology of autism spectrum disorders. Dialogues Clin Neurosci, 2009, 11: 35-43

7 Berkel S, Marshall CR, Weiss B, Howe J, Roeth R, Moog U, Endris V, Roberts W, Szatmari P, Pinto D, Bonin M, Riess A, Engels H, Sprengel R, Scherer SW, Rappold GA. Mutations in the SHANK2 synaptic scaffolding gene in autism spectrum disorder and mental retardation. Nat Genet, 2010, 42: 489-491

8 Leblond CS, Heinrich J, Delorme R, Proepper C, Betancur C, Huguet G, Konyukh M, Chaste P, Ey E, Rastam M, Anckarsäter H, Nygren G, Gillberg IC, Melke J, Toro R, Regnault B, Fauchereau F, Mercati O, Lemière N, Skuse D, Poot M, Holt R, Monaco AP, Järvelä I, Kan- tojärvi K, Vanhala R, Curran S, Collier DA, Bolton P, Chiocchetti A, Klauck SM, Poustka F, Freitag CM, Waltes R, Kopp M, Duketis E, Bacchelli E, Minopoli F, Ruta L, Battaglia A, Mazzone L, Maestrini E, Sequeira AF, Oliveira B, Vicente A, Oliveira G, Pinto D, Scherer SW, Zelenika D, Delepine M, Lathrop M, Bonneau D, Guinchat V, Devillard F, Assouline B, Mouren MC, Leboyer M, Gillberg C, Boeckers TM, Bourgeron T. Genetic and functional analyses of SHANK2 mutations suggest a multiple hit model of autism spectrum disorders. PLoS Genet, 2012, 8: e1002521

9 Sudhof TC. Neuroligins and neurexins link synaptic function to cognitive disease. Nature, 2008, 455: 903-911

10 Jamain S, Quach H, Betancur C, Råstam M, Colineaux C, Gillberg IC, Soderstrom H, Giros B, Leboyer M, Gillberg C, Bourgeron T; Paris Autism Research International Sibpair Study. Mutations of the X-linked genes encoding neuroligins NLGN3 and NLGN4 are associated with autism. Nat Genet, 2003, 34: 27-29

11 Laumonnier F, Bonnet-Brilhault F, Gomot M, Blanc R, David A, Moizard MP, Raynaud M, Ronce N, Lemonnier E, Calvas P, Laudier B, Chelly J, Fryns JP, Ropers HH, Hamel BC, Andres C, Barthélémy $\mathrm{C}$, Moraine $\mathrm{C}$, Briault S. X-linked mental retardation and autism are associated with a mutation in the NLGN4 gene, a member of the neuroligin family. Am J Hum Genet, 2004, 74: 552-557

12 Yan J, Oliveira G, Coutinho A, Yang C, Feng J, Katz C, Sram J, Bockholt A, Jones IR, Craddock N, Cook EH Jr, Vicente A, Sommer SS. Analysis of the neuroligin 3 and 4 genes in autism and other neuropsychiatric patients. Mol Psychiatry, 2005, 10: 329-332

13 Ylisaukko-oja T, Rehnstrom K, Auranen M, Vanhala R, Alen R, Kempas E, Ellonen P, Turunen JA, Makkonen I, Riikonen R, Nieminen-von Wendt T, von Wendt L, Peltonen L, Järvelä I. Analysis of four neuroligin genes as candidates for autism. Eur J Hum Genet, 2005, 13: 1285-1292

14 Lawson-Yuen A, Saldivar JS, Sommer S, Picker J. Familial deletion within NLGN4 associated with autism and Tourette syndrome. Eur J Hum Genet, 2008, 16: 614-618

15 Marshall CR, Noor A, Vincent JB, Lionel AC, Feuk L, Skaug J, Shago M, Moessner R, Pinto D, Ren Y, Thiruvahindrapduram B, Fiebig A, Schreiber S, Friedman J, Ketelaars CE, Vos YJ, Ficicioglu C, Kirkpatrick S, Nicolson R, Sloman L, Summers A, Gibbons CA, Teebi A, Chitayat D, Weksberg R, Thompson A, Vardy C, Crosbie V, Luscombe S, Baatjes R, Zwaigenbaum L, Roberts W, Fernandez B, Szatmari P, Scherer SW. Structural variation of chromosomes in autism spectrum disorder. Am J Hum Genet, 2008, 82: 477-488

16 Daoud H, Bonnet-Brilhault F, Vedrine S, Demattéi MV, Vourc'h P, Bayou N, Andres CR, Barthélémy C, Laumonnier F, Briault S. Autism and nonsyndromic mental retardation associated with a de novo mutation in the $N L G N 4 X$ gene promoter causing an increased expression level. Biol Psychiatry, 2009, 66: 906-910

17 Pampanos A, Volaki K, Kanavakis E, Papandreou O, Youroukos S, Thomaidis L, Karkelis S, Tzetis M, Kitsiou-Tzeli S. A substitution involving the NLGN4 gene associated with autistic behavior in the Greek population. Genet Test Mol Biomarkers, 2009, 13: 611-615

18 Zhang C, Milunsky JM, Newton S, Ko J, Zhao G, Maher TA, TagerFlusberg H, Bolliger MF, Carter AS, Boucard AA, Powell CM, Südhof TC. A neuroligin-4 missense mutation associated with autism impairs neuroligin-4 folding and endoplasmic reticulum export. J Neurosci, 2009, 29: 10843-10854

19 Durand CM, Betancur C, Boeckers TM, Bockmann J, Chaste P, Fauchereau F, Nygren G, Rastam M, Gillberg IC, Anckarsäter H, Sponheim E, Goubran-Botros H, Delorme R, Chabane N, MourenSimeoni MC, de Mas P, Bieth E, Rogé B, Héron D, Burglen L, Gillberg $\mathrm{C}$, Leboyer M, Bourgeron T. Mutations in the gene encoding the synaptic scaffolding protein SHANK3 are associated with autism spectrum disorders. Nat Genet, 2007, 39: 25-27

20 Gauthier J, Spiegelman D, Piton A, Lafrenière RG, Laurent S, St-Onge J, Lapointe L, Hamdan FF, Cossette P, Mottron L, Fombonne E, Joober R, Marineau C, Drapeau P, Rouleau GA. Novel de novo SHANK3 mutation in autistic patients. Am J Med Genet B Neuropsychiatr Genet, 2009, 150B: 421-424

21 Sheng M, Kim E. The Shank family of scaffold proteins. J Cell Sci, 
2000, 113: 1851-1856

22 Sato D, Lionel C, Leblond CS, Prasad A, Pinto D, Walker S, O'Connor I, Russell C, Drmic IE, Hamdan FF, Michaud JL, Endris V, Roeth R, Delorme R, Huguet G, Leboyer M, Rastam M, Gillberg C, Lathrop M, Stavropoulos DJ, Anagnostou E, Weksberg R, Fombonne E, Zwaigenbaum L, Fernandez BA, Roberts W, Rappold GA, Marshall CR, Bourgeron T, Szatmari P, Scherer SW. SHANK1 deletions in males with autism spectrum disorder. Am J Hum Genet, 2012, 90: 879-887

23 Jiang YH, Ehlers MD. Modeling autism by SHANK gene mutations in mice. Neuron, 2013, 78: 8-27

24 Boeckers TM, Winter C, Smalla KH, Kreutz MR, Bockmann J, Seidenbecher C, Garner CC, Gundelfinger ED. Prolinerich synapse-associated proteins ProSAP1 and ProSAP2 interact with synaptic proteins of the SAPAP/GKAP family. Biochem Biophys Res Commun, 1999, 264: 247-252

25 Naisbitt S, Kim E, Tu JC, Xiao B, Sala C, Valtschanoff J, Weinberg RJ, Worley PF, Sheng M. Shank, a novel family of postsynaptic density proteins that binds to the NMDA receptor/PSD-95/GKAP complex and cortactin. Neuron, 1999, 23: 569-582

26 Bruckner K, Pablo Labrador J, Scheiffele P, Herb A, Seeburg PH, Klein R. EphrinB ligands recruit GRIP family PDZ adaptor proteins into raft membrane microdomains. Neuron, 1999, 22: 511-524

27 Dong H, O'Brien RJ, Fung ET, Lanahan AA, Worley PF, Huganir RL. GRIP: a synaptic PDZ domain-containing protein that interacts with AMPA receptors. Nature, 1997, 386: 279-284

28 Tu JC, Xiao B, Yuan JP, Lanahan AA, Leoffert K, Li M, Linden DJ, Worley PF. Homer binds a novel proline-rich motif and links group 1 metabotropic glutamate receptors with IP3 receptors. Neuron, 1998, 21: 717-726

29 Xiao B, Tu JC, Petralia RS, Yuan JP, Doan A, Breder CD, Ruggiero A, Lanahan AA, Wenthold RJ, Worley PF. Homer regulates the association of group 1 metabotropic glutamate receptors with multivalent complexes of homer-related, synaptic proteins. Neuron, 1998, 21: 707-716

30 Wu H, Parsons JT. Cortactin, an 80/85-kilodalton pp60src substrate, is a filamentous actin-binding protein enriched in the cell cortex. $\mathrm{J}$ Cell Biol, 1993, 120: 1417-1426

31 Du Y, Weed SA, Xiong WC, Marshall TD, Parsons JT. Identification of a novel cortactin SH3 domain-binding protein and its localization to growth cones of cultured neurons. Mol Cell Biol, 1998, 18: 5838-5851

32 Boeckers TM, Liedtke T, Spilker C, Dresbach T, Bockmann J, Kreutz MR, Gundelfinger ED. C-terminal synaptic targeting elements for postsynaptic density proteins ProSAP1/Shank2 and ProSAP2/ Shank3. J Neurochem, 2005, 92: 519-524

33 Grabrucker AM, Vaida B, Bockmann J, Boeckers TM. Efficient targeting of proteins to post-synaptic densities of excitatory synapses using a novel pSDTarget vector system. J Neurosci Methods, 2009, 181: 227-234

34 Sala C, Piëch V, Wilson NR, Passafaro M, Liu G, Sheng M. Regulation of dendritic spine morphology and synaptic function by Shank and Homer. Neuron, 2001, 31: 115-130

35 Yao I, Hata Y, Hirao K, Deguchi M, Ide N, Takeuchi M, Takai Y. Synamon, a novel neuronal protein interacting with synapseassociated protein 90/Postsynaptic density-95-associated protein. J Biol Chem, 1999, 274: 27463-27466

36 Zitzer H, Honck HH, Bachner D, Richter D, Kreienkamp HJ. Soma- tostatin receptor interacting protein defines a novel family of multidomain proteins present in human and rodent brain. J Biol Chem, 1999, 274: 32997-33001

37 Hung AY, Futai K, Sala C, Valtschanoff JG, Ryu J, Woodworth MA, Kidd FL, Sung CC, Miyakawa T, Bear MF, Weinberg RJ, Sheng M. Smaller dendritic spines, weaker synaptic transmission, but enhanced spatial learning in mice lacking Shank1. J Neurosci, 2008, 28: $1697-1708$

38 Tao-Cheng JH, Dosemeci A, Gallant PE, Smith C, Reese T. Activity induced changes in the distribution of Shanks at hippocampal synapses. Neuroscience, 2010, 168: 11-17

39 Grabrucker AM, Knight MJ, Proepper C, Bockmann J, Joubert M, Rowan M, Nienhaus GU, Garner CC, Bowie JU, Kreutz MR, Gundelfinger ED, Boeckers TM. Concerted action of zinc and ProSAP/Shank in synaptogenesis and synapse maturation. EMBO J, 2011, 30: 569-581

40 Beri S, Tonna N, Menozzi G, Bonaglia MC, Sala C, Giorda R. DNA methylation regulates tissue-specific expression of Shank3. J Neurochem, 2007, 101: 1380-1391

41 Silverman JL, Turner SM, Barkan CL, Tolu SS, Saxena R, Hung AY, Sheng M, Crawley JN. Sociability and motor functions in Shank1 mutant mice. Brain Res, 2011, 1380: 120-137

42 Wöhr M, Roullet FI, Hung AY, Sheng M, Crawley JN. Communication impairments in mice lacking Shankl: reduced levels of ultrasonic vocalizations and scent marking behavior. PLoS One, 2011, 6: e20631

43 Ehret G. Left hemisphere advantage in the mouse brain for recognizing ultrasonic communication calls. Nature, 1987, 325: 249-251

44 Ehret G, Haack B. Ultrasound recognition in house mice: key-stimulus configuration and recognition mechanisms. J Comp Physiol, 1982, 148: 245-251

45 Sewell GD. Ultrasonic communication in rodents. Nature, 1970, 227: 410

46 Smith JC. Responses to adult mice to models infant calls. J Comp Physiol Psychol, 1976, 90: 1105-1115

47 Chadman KK, Gong S, Scattoni ML, Boltuck SE, Gandhy SU, Heintz N, Crawley JN. Minimal aberrant behavioral phenotypes of neuroligin-3 R451C knockin mice. Autism Res, 2008, 1: 147-158

48 Gaub S, Groszer M, Fisher SE, Ehret G. The structure of innate vocalizations in Foxp2-deficient mouse pups. Genes Brain Behav, 2010, 9: $390-401$

49 Shu W, Cho JY, Jiang Y, Zhang M, Weisz D, Elder GA, Schmeidler J, De Gasperi R, Sosa MA, Rabidou D, Santucci AC, Perl D, Morrisey E, Buxbaum JD. Altered ultrasonic vocalization in mice with a disruption in the Foxp2 gene. Proc Natl Acad Sci USA, 2005, 102: 9643-9648

50 Winslow JT, Hearn EF, Ferguson J, Young LJ, Matzuk MM, Insel TR. Infant vocalization, adult aggression, and fear behavior of an oxytocin null mutant mouse. Horm Behav, 2000, 37: 145-155

51 Young DM, Schenk AK, Yang SB, Jan YN, Jan LY. Altered ultrasonic vocalizations in a tuberous sclerosis mouse model of autism. Proc Natl Acad Sci USA, 2010, 107: 11074-11079

52 Lennertz L, Wagner M, Wölwer W, Schuhmacher A, Frommann I, Berning J, Schulze-Rauschenbach S, Landsberg MW, Steinbrecher A, Alexander M, Franke PE, Pukrop R, Ruhrmann S, Bechdolf A, Gaebel W, Klosterkötter J, Häfner H, Maier W, Mössner R. A promoter variant of SHANK1 affects auditory working memory in schizophrenia patients and in subjects clinically at risk for psychosis. Eur Arch Psychiatry Clin Neurosci, 2012, 262: 117-112

Open Access This article is distributed under the terms of the Creative Commons Attribution License which permits any use, distribution, and reproduction in any medium, provided the original author(s) and source are credited. 